\title{
Plant-Based COVID-19 Vaccines: Current Status, Design, and Development Strategies of Candidate Vaccines
}

\author{
Puna Maya Maharjan ${ }^{1}$ (D) and Sunghwa Choe ${ }^{2,3, *(D)}$ \\ 1 G+FLAS Life Sciences, 123 Uiryodanji-gil, Osong-eup, Heungdeok-gu, Cheongju-si 28161, Korea; \\ punamaya.maharjan@gflas.com \\ 2 G+FLAS Life Sciences, 38 Nakseongdae-ro, Gwanak-gu, Seoul 08790, Korea \\ 3 School of Biological Sciences, College of Natural Sciences, Seoul National University, Gwanak-gu, \\ Seoul 08826, Korea \\ * Correspondence: shchoe@snu.ac.kr
}

check for updates

Citation: Maharjan, P.M.; Choe, S. Plant-Based COVID-19 Vaccines: Current Status, Design, and Development Strategies of Candidate Vaccines. Vaccines 2021, 9, 992. https: / / doi.org/10.3390/ vaccines 9090992

Academic Editor: Claudia Sardu

Received: 23 July 2021

Accepted: 31 August 2021

Published: 6 September 2021

Publisher's Note: MDPI stays neutral with regard to jurisdictional claims in published maps and institutional affiliations.

Copyright: (C) 2021 by the authors Licensee MDPI, Basel, Switzerland. This article is an open access article distributed under the terms and conditions of the Creative Commons Attribution (CC BY) license (https:/ / creativecommons.org/licenses/by/ $4.0 /)$.

\begin{abstract}
The prevalence of the coronavirus disease 2019 (COVID-19) pandemic in its second year has led to massive global human and economic losses. The high transmission rate and the emergence of diverse SARS-CoV-2 variants demand rapid and effective approaches to preventing the spread, diagnosing on time, and treating affected people. Several COVID-19 vaccines are being developed using different production systems, including plants, which promises the production of cheap, safe, stable, and effective vaccines. The potential of a plant-based system for rapid production at a commercial scale and for a quick response to an infectious disease outbreak has been demonstrated by the marketing of carrot-cell-produced taliglucerase alfa (Elelyso) for Gaucher disease and tobaccoproduced monoclonal antibodies (ZMapp) for the 2014 Ebola outbreak. Currently, two plant-based COVID-19 vaccine candidates, coronavirus virus-like particle (CoVLP) and Kentucky Bioprocessing (KBP)-201, are in clinical trials, and many more are in the preclinical stage. Interim phase 2 clinical trial results have revealed the high safety and efficacy of the CoVLP vaccine, with 10 times more neutralizing antibody responses compared to those present in a convalescent patient's plasma. The clinical trial of the CoVLP vaccine could be concluded by the end of 2021, and the vaccine could be available for public immunization thereafter. This review encapsulates the efforts made in plant-based COVID-19 vaccine development, the strategies and technologies implemented, and the progress accomplished in clinical trials and preclinical studies so far.
\end{abstract}

Keywords: COVID-19 vaccine; SARS-CoV-2; plant-based vaccine; VLP; subunit vaccine; clinical trial; Nicotiana benthamaiana; RBD; spike protein; glycoengineering

\section{Introduction}

Since the first report on the emergence of the severe acute respiratory syndrome coronavirus 2 (SARS-CoV-2) virus causing coronavirus disease 2019 (COVID-19) in China at the end of 2019, it has spread across 220 countries and territories, infected 160 million people, and caused the deaths of 3.3 million people as of June 19, 2021 [1]. The coalescence of advanced biotechnology and global scientists' efforts made the COVID-19 vaccine available for public immunization within a year of SARS-CoV-2's emergence, faster than ever in vaccine history. To date, 8 vaccines are approved for full use, 8 are authorized for limited use, 31 are in phase 3 clinical trials, 37 are in phase 2 clinical trials, 51 are in phase 1 clinical trials, and 185 are in preclinical studies [2,3]. All the potential vaccine production platforms have been exploited to develop a COVID-19 vaccine.

Egg-based vaccine production remains the most effective method for commercial production due to its excellent production capacity and low production cost [4]. However, the technology cannot be used for the COVID-19 pandemic because of the long production time and, most importantly, the inability of SARS-CoV-2 to replicate in hens' egg cells [5]. Instead, many vaccine developers prefer advanced platforms, such as DNA, RNA, protein 
subunits, inactivated viruses, nonreplicating viral vector, virus-like particles (VLP), live attenuated viruses, inactivated virus, replicating viral vector $(\mathrm{VVr})$, nonreplicating viral vector (VVnr), replicating viral vector with antigen-presenting cells, and nonreplicating viral vector with antigen-presenting cells $[2,6,7]$. Recombinant DNA technology-based production has dominated COVID-19 vaccine development, narrowing the whole virus vaccine to $18 \%$ of the total vaccines in clinical trials (Figure 1 ).

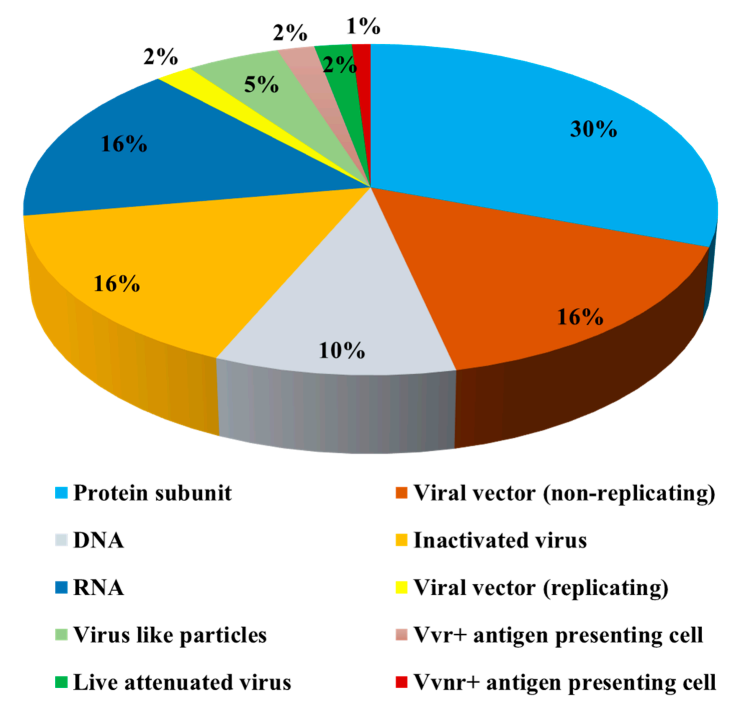

Figure 1. Vaccine platforms used to develop coronavirus disease 2019 (COVID-19) vaccine candidates. Data source: World Health Organization (WHO), 19 June 2021.

Plant-based production has received immense attention among vaccine researchers as a potential alternative to rapidly produce affordable COVID-19 vaccines and other therapeutics [8-18]. Plant-based production offers several advantages, such as low cost, rapidity, scalability, and safety. Moreover, plants can produce glycosylated recombinant proteins, which is not possible in an Escherichia coli-based culture system. As the glycosylation pattern affects the bioactivity of protein-based vaccines and therapeutics, recombinant proteins with a variable glycan pattern and improved efficacy can be generated by controlling glycosylation at different levels via glycoengineering of the host plant [19-21]. The technology has been used to produce a variety of pharmaceuticals, including vaccines, monoclonal antibodies, human growth hormones, immunomodulators, diagnostic reagents, and medical devices; some of them are in clinical trials [14,22-26]. Several correctly folded antigens against numerous infectious viruses, including influenza, Ebola, dengue, rotavirus, and norovirus, have been produced in plants and can induce neutralizing antibodies in both the animal model and humans [27-31].

The plant-based system is feasible to produce various types of vaccine, such as protein subunit, VLP, chimeric VLP (cVLP), and multiepitope vaccines, with implications of transient and stable expression [13]. Stable expression is suitable for producing vaccines that are continuously required in large quantities, because once the transgenic plant-expressing specific antigen is prepared, the product can be harvested for several generations, ensuring continuous manufacturing and availability [32]. In addition, when the transgenic system is applied to a host plant, such as rice, potato, or lettuce, an edible vaccine that induces humoral as well as cellular immune responses can be produced [33-38]. In contrast, the transient expression system can produce a target antigen within one week after introducing an antigen-coding sequence into plants, compared to one or several years via the transgenic expression system [18]. This unique feature of the transient expression system for rapid vaccine production tends to be the first and an excellent choice to produce a vaccine, especially in an emergency such as the COVID-19 pandemic. The plant transient expression system is much faster than any other system and produces a vaccine in 20 days after the protein amino acid sequence becomes available [39], with a yield of up to $4 \mathrm{~g}$ of green fluorescent 
protein (GFP)/ $\mathrm{kg}$ fresh weight [40]. This enables the production of up to 10 million doses of the vaccine per month [41], making the system ideal for bulk production and for a quick response to an unexpected disease outbreak and pandemic.

The world's first plant-produced vaccine was approved for Newcastle disease virus (NDV) by the US Department of Agriculture in 2006 for poultry [42,43]. The first plantproduced pharmaceutical approved by the US Food and Drug Administration (USFDA) for human use in 2012 was taliglucerase alfa enzyme (Elelyso), produced from genetically engineered carrot cells for treating Gaucher disease [27,44,45]. Researchers have attempted to develop a vaccine for COVID-19 by expressing SARS-CoV S1 protein in transgenic tobacco, tomato, and transplantomic lettuce [46,47]. Oral immunization of mice with S1 protein-expressing transgenic tomato induced a high level of SARS-CoV-specific immunoglobulin IgA, while parenteral immunization with tobacco produced S1-induced SARS-CoV-specific IgG in mice [46]. The plant-based recombinant protein production approach has been implemented for the development of vaccines, diagnostic reagents, and therapeutics for COVID-19 and has progressed into clinical trials [48-57]. The coronavirus virus-like particle (CoVLP) vaccine is in phase 3 and Kentucky Bioprocessing (KBP)-201 in phase $1 / 2$ clinical trials, while IBIO-200, IBIO-201, IBIO-202, Baiya SARS-CoV vax 1 , and many more are in the preclinical phase of development (Table 1) [51,58-60].

Table 1. Plant-based coronavirus disease 2019 (COVID-19) vaccine candidates.

\begin{tabular}{|c|c|c|c|c|c|c|}
\hline Vaccine & $\begin{array}{l}\text { Vaccine } \\
\text { Platform }\end{array}$ & $\begin{array}{c}\text { Target } \\
\text { Antigen }\end{array}$ & $\begin{array}{c}\text { Development } \\
\text { Phase }\end{array}$ & Developer & Country & References \\
\hline CoVLP & VLP & $\mathrm{S}$ protein & Phase $2 / 3$ & Medicago & Canada & {$[50,58]$} \\
\hline KBP-201 & cVLP & RBD & Phase $1 / 2$ & $\begin{array}{c}\text { Kentucky } \\
\text { Bioprocessing }\end{array}$ & United State & {$[59]$} \\
\hline IBIO-200 & VLP & $\mathrm{S}$ protein & preclinical & iBio & United State & {$[51]$} \\
\hline IBIO-201 & $\begin{array}{c}\text { Conjugated } \\
\text { protein subunit }\end{array}$ & $\mathrm{S}$ protein & preclinical & iBio & United State & {$[51]$} \\
\hline IBIO-202 & Protein subunit & N protein & preclinical & iBio & United State & {$[51]$} \\
\hline RBD & Protein subunit & RBD & preclinical & $\begin{array}{c}\text { G+FLAS Life } \\
\text { Sciences }\end{array}$ & South Korea & {$[57]$} \\
\hline Baiya SARS-CoV Vax 1 & Protein subunit & NM * & preclinical & Baiya phytopharm & Thailand & {$[60]$} \\
\hline S1 protein & Protein subunit & S1 protein & preclinical & Akdeniz University & Turkey & {$[61]$} \\
\hline RBD & Protein subunit & RBD & preclinical & Akdeniz University & Turkey & {$[61]$} \\
\hline $\mathrm{N}$ protein & Protein subunit & N protein & preclinical & Akdeniz University & Turkey & {$[61]$} \\
\hline
\end{tabular}

* Not mentioned.

This review describes the recent progress in the development of plant-based COVID-19 vaccines and analyzes the research, design, and development strategies and the technologies employed so far by different biotech companies and research groups. Most importantly, it discusses recently available results of the clinical trials of plant-based COVID-19 vaccine candidates. The information provided in this review is based on the electronic data available in PubMed, Google Scholar, Google Search, clinical trials, different biotech companies' websites, universities' websites, and online news portals.

\section{Plant-Based Vaccine Production for Epidemic Response}

Plant-based vaccine production is a rapid, robust, scalable, and effective technology for virus outbreak response. In the 2014 Ebola outbreak, ZMapp, a cocktail of monoclonal antibodies produced in the tobacco plant, was administered to six affected people at a dose of $50 \mathrm{mg} / \mathrm{kg}$ body weight and resulted in the recovery of five patients $[62,63]$. The product was in the experimental phase at the time of the outbreak and received authorization by the USFDA for emergency compassionate approval for human use and clinical study in 
Africa [9,52]. This showcased the relevance of plant-based biopharmaceutical production technology and its speed, scalability, and efficacy to the world.

Plant-based vaccine production was prioritized as a potential rapid production technology to manufacture the influenza vaccine under the Blue Angel program, launched by the US Defense Advanced Research Projects Agency (DARPA), in order to accelerate vaccine production in response to the $2009 \mathrm{H} 1 \mathrm{~N} 1$ influenza pandemic. In 2012, the program, in collaboration with Medicago, Canada, successfully manufactured 10 million doses of monovalent H1N1 VLP vaccine in tobacco plants within 30 days, accomplishing the proof-of-concept objective to demonstrate the potential scalability and rapidity of plant production to combat the influenza pandemic [41]. Numerous plant-based vaccines against a wide range of pathogens and diseases, including influenza, Ebola, rabies, hepatitis B, norovirus malaria, anthrax, and rotavirus, have entered different phases of clinical trials (Table 2) $[27,36,48,50,58,59,62,64-78]$. Recently, the quadrivalent vaccine developed by Medicago for seasonal influenza has completed a phase 3 clinical trial [48]. Advancements in plant-based pharmaceuticals in recent decades have strengthened the technology, and it is now a promising production system for fighting the COVID-19 pandemic. Currently, two plant-produced vaccines are in clinical trials and many others are in preclinical stages (Table 1). 
Table 2. Plant-based vaccines in clinical trials.

\begin{tabular}{|c|c|c|c|c|c|c|c|}
\hline Disease & Pathogen & Antigen & Host Plant & Expression System & $\begin{array}{c}\text { Route of } \\
\text { Administration }\end{array}$ & Clinical Phase & References \\
\hline Seasonal Influenza & $\begin{array}{c}\text { A/H1N1, A/H3N2, } \\
\text { B/Brisbane, B/Phuket }\end{array}$ & HA Quadrivalent & Nicotiana benthamiana & Transient VLP & Intramuscular & Phase 3 completed & {$[48,66]$} \\
\hline COVID-19 & SARS-CoV-2 & Spike protein & Nicotiana benthamiana & Transient VLP & Intramuscular & Phase 3 & {$[50,58]$} \\
\hline COVID-19 & SARS-CoV-2 & RBD & Nicotiana benthamiana & Transient cVLP & Intramuscular & Phase $1 / 2$ & [59] \\
\hline Influenza & H5N1 & HA (H5) & Nicotiana benthamiana & Transient & Intramuscular & Phase 2 completed & [79] \\
\hline Influenza & H5N1 & HA & Nicotiana benthamiana & Transient & Intramuscular & Phase 1 completed & [73] \\
\hline Malaria & Plasmodium falciparum & Pfs25 VLP & Nicotiana benthamiana & Transient cVLP & Intramuscular & Phase 1 completed & {$[71,72]$} \\
\hline Influenza & H7N9 & HA (H7) & Nicotiana benthamiana & Transient & Intramuscular & Phase 1 & {$[27,74]$} \\
\hline Cholera & Vibrio Cholera & СТВ & Rice & Transgenic & Edible & Phase 1 & [75] \\
\hline Hepatitis B & $\mathrm{HBV}$ & HBsAg & Potato & Transgenic & Edible & Phase 1 & [76] \\
\hline Hepatitis B & HBV & HBsAg & Lettuce & Transgenic & Edible & Phase 1 & [35] \\
\hline Rabies & Rabies virus & G protein & Spinach & Transient & Oral & Phase 1 & {$[36]$} \\
\hline Gastroenteritis & Norwalk virus & Capsid protein & Potato & Transgenic & Oral & Phase 1 & [77] \\
\hline Anthrax & Bacillus anthracis & Protective antigen & Nicotiana benthamiana & Transient & $\mathrm{N}$ & Phase I & {$[64]$} \\
\hline Gastroenteritis & Rotavirus & $\mathrm{NM} *$ & Nicotiana benthamiana & Transient VLP & NA & Phase 1 & [65] \\
\hline
\end{tabular}

* Not mentioned; COVID-19, coronavirus disease 2019. 
Plant-based production has been used to develop vaccines against several epidemics. Vaccine development for the devastating plague pandemic was attempted by expressing F1 and $\mathrm{V}$ antigens in tobacco and tomato plants, which induced $50 \%$ protection in mice and 88\% protection in nonhuman primates after a Yersinia pestis challenge (Table 3) [69,80-82]. Similarly, the tobacco-produced vaccine for yellow fever disease, targeting the envelope protein, elicited up to $100 \%$ of protection in mice and a cellular and humoral immune response in monkeys after pathogen challenge (Table 3) [82-84]. Numerous epitopes of the envelope glycoprotein and capsid proteins of human immunodeficiency virus (HIV) have been expressed in plants, such as lettuce, tobacco, arabidopsis, moss, and carrot, in order to develop a vaccine against acquired immunodeficiency disease, and they have been found to be effective in inducing a humoral and cellular immune response in mice (Table 3) $[34,82,85,86]$. In addition, plant-produced vaccines against dengue and Ebola have demonstrated the induction of antibodies in animal models [87-89]. 
Table 3. Plant-based vaccines for epidemics in preclinical study.

\begin{tabular}{|c|c|c|c|c|c|}
\hline Disease & Antigen & Host Plant & Expression System & Efficacy in Preclinical Study & References \\
\hline Plague & F1 and V & Tomato & Transgenic & $50 \%$ protection in mice & [80] \\
\hline Plague & $\mathrm{F} 1$ and $\mathrm{V}$ & Nicotiana benthamiana & Transient & $88 \%$ protection in monkeys & [69] \\
\hline HIV / AIDS Pandemic & HIV multi proteins & Nicotiana benthamiana & Transplantomic & Induced humoral and cellular immune response in mice. & [82] \\
\hline HIV / AIDS Pandemic & p24 & Arabidopsis thaliana & Transgenic & Induced humoral immune response in mice. & [86] \\
\hline Dengue fever & SP and NSPs & Nicotiana benthamiana & Transient VLP & Induced humoral immune response in mice. & [89] \\
\hline Yellow fever & Envelop protein & Nicotiana benthamiana & Transient & $\begin{array}{l}77 \% \text { protection in mice and induced cellular and humoral } \\
\text { immune response in monkey. }\end{array}$ & [83] \\
\hline Yellow fever & Envelop protein & Nicotiana benthamiana & Transient & $\begin{array}{l}100 \% \text { protection in mice and induced cellular and } \\
\text { humoral immune response in monkey. }\end{array}$ & [84] \\
\hline Ebola & Glycoprotein (GP1) & Nicotiana benthamiana & Transient & Induced anti-Ebola antibodies in mice. & [87] \\
\hline
\end{tabular}

HIV/AIDS, human immunodeficiency virus/acquired immunodeficiency disease. 


\section{CoVLP: A COVID-19 VLP Vaccine in a Phase 2/3 Clinical Trial}

Of the five COVID-19 VLP vaccines in clinical trials listed by the World Health Organization (WHO), one plant-based VLP vaccine is in a phase 3 clinical trial. Medicago developed the CoVLP vaccine within 20 days after receiving the SARS-CoV-2 genetic sequence [39]. After encouraging positive results from phase 1 and completion of phase 2 studies, the company announced the beginning of a phase 3 clinical trial on 16 March 2021 [58].

To design a VLP, the company selected the spike protein (S protein) of SARS-CoV-2, the most widely used target antigen for COVID-19 vaccines among the structural envelope protein $(\mathrm{E})$, membrane protein $(\mathrm{M})$, and nucleocapsid protein $(\mathrm{N})$ because of its high immunogenicity and crucial role in viral cell entry [90-92]. S protein is a surface glycoprotein that triggers the entry of the virus into the human cell via binding with the receptor angiotensin-converting enzyme 2 (ACE2), prevalent in human respiratory tract cells $[92,93]$. Most of the SARS-CoV-2-neutralizing antibodies from COVID-19-recovered patients were directed against the $S$ protein [94-96]. Hence, the antibodies generated after vaccination with an S-protein-based vaccine can target the $S$ protein to inhibit the natural infection by interfering with the binding of the virus and ACE2 during cell entry.

Medicago's CoVLP vaccine mimics the surface structure of the natural SARS-CoV2 virus with an antigenic moiety but is non-infectious and nonreplicating as it lacks the replicating viral RNA. Hence, the VLP is safe and can stimulate an immune response against the virus when administered to humans. The VLP is an advanced form of recombinant antigen, compatible and favorable for plant-based vaccine production. The VLP is also an improved alternative to recombinant antigens and is highly immunogenic because of its complex external structure similar to that of natural viral particles [97-99]. VLP-based vaccines share most of the properties of the natural virus, such as a repetitive surface geometry, a particulate nature, and the ability to stimulate innate and adaptive immune responses, but without the ability to replicate, making the VLP a protective and safe mode of vaccination [29,100-105]. Moreover, the manufacturing of highly infectious pandemic virus particles requires high-level safety measurement; however, VLP production does not require any costly safety measurement since VLPs are composed of only non-infectious recombinant proteins. The VLP platform has been deployed to develop vaccines for the recurring influenza pandemic [29,106-108]. The fast mass production of plant factoryderived VLPs could be a promising vaccine-manufacturing platform to cope with the COVID-19 pandemic.

For rapid vaccine production, Medicago has developed a proprietary high-throughput screening platform, VLPExpress, which enables testing of more than 200 different expression approaches per week. The platform has significantly accelerated the development of Medicago's products and has enabled the production of a broad range of VLP-based vaccines as well as antibody candidates. Moreover, Medicago is developing an antigendisplaying platform to produce an effective VLP using an envelope and capsid protein that warrants incorporation and displays diverse antigens [109].

Medicago's CoVLP vaccine is formulated with two types of adjuvants, ASO3 and CpG 1018. Vaccine formulation with an adjuvant is essential in designing a vaccine for a pandemic, since it facilitates a reduction in the quantity required for mass immunization by enhancing the efficacy of the vaccine, especially in the case of recombinant subunit vaccines that have low immunogenicity compared with inactivated and live-attenuated vaccines $[79,110-112]$. Therefore, to enhance the immunogenicity of the CoVLP vaccine by administration of an adjuvant, Medicago collaborated with global healthcare companies GlaxoSmithKline (GSK) and Dynavax Technologies for promising adjuvants. Dynavax's CpG 1018 is a Toll-like receptor 9 antagonist adjuvant composed of a short (22-mer) oligonucleotide sequence containing CpG motifs [113]. CpG 1018 is effective and safe and is formulated with Dynavax's hepatitis B vaccine, HEPLISAV- $B^{\circledR}$, approved by the USFDA $[114,115]$. The other adjuvant, AS03 from GSK, is composed of $\alpha$-tocopherol, 
squalene, and polysorbate 80 in an oil-in-water emulsion and has been used in GSK's Pandemrix, an H1N1 influenza vaccine [116,117].

Medicago's first product, a quadrivalent VLP vaccine for seasonal influenza, completed the phase 3 clinical trial in 2020 and was the first plant-derived human vaccine that was well tolerated and provided substantial protection from influenza viruses in adults [48]. The company has more vaccine candidates in the production pipeline, including one against rotavirus and influenza; both are in phase 1 clinical trials [118]. Furthermore, it has produced a fully formulated HA VLP vaccine within 3 weeks of the release of the genetic sequence for the A/H1N1(A/California/04/09) strain [107]. These findings prove the capacity of the plant-based platform for rapid vaccine production, one of the most important aspects of vaccine development at the time of a pandemic. Medicago demonstrated its capacity for mass-scale production by producing 10 million doses of the monovalent H1N1 VLP vaccine in tobacco plants within 30 days in association with the DARPA Blue Angel program in 2012 [41]. The company expects to produce as many as 80 million doses from 2021 and over 1 billion doses of COVID-19 vaccines annually after the completion of a large-scale factory construction in Quebec in 2023 [118]. The success of the influenza VLP vaccine development has bolstered Medicago to progress the CoVLP vaccine to clinical trials in a short period.

\section{Clinical Trial Results for CoVLP}

The provisional results of the phase 1 clinical trial of Medicago's CoVLP vaccine were reported on November 10, 2020 [119]. In the trial, 3.76, 7.5, and $15 \mu \mathrm{g}$ of CoVLP with or without ASO3 and CpG 1018 were intramuscularly injected into 18-55-year-olds at an interval of 21 days in a randomized, partially blinded clinical trial (NCT04450004) [120]. The immunogenicity results demonstrated that adjuvant formulations have a greater potential to improve humoral and cellular immune responses to the CoVLP vaccine compared with non-adjuvant formulations. All subjects receiving the adjuvanted vaccine developed neutralizing antibodies as the immune response after the second dose in all dose groups. All subjects receiving CoVLP formulated with ASO3 developed anti-spike IgG after a single dose. The antibody levels observed in vaccinated subjects were higher than those observed in the convalescent sera of people who recovered from COVID-19 [68]. The vaccine formulation with adjuvants significantly enhanced cellular Th1 immune responses in subjects receiving the 3.75 or $7.5 \mu \mathrm{g}$ dose. However, no dose-dependent effect was observed for CoVLP formulated with CpG 1018, which might be the reason for its exclusion from the phase $2 / 3$ clinical trial. No serious adverse effects were observed, except for mild-to-moderate short-term side effects $[68,119]$.

With encouraging positive results, the CoVLP vaccine entered the phase $2 / 3$ clinical trial (NCT04636697) on 12 November 2020 [121]. The trial was designed as a randomized, observer-blind, placebo-controlled study to evaluate the safety and immunogenicity of the recombinant CoVLP formulated with an adjuvant in adults aged 18-64 years and the elderly (aged 65+ years).

The trial employed a single dose, $3.75 \mu \mathrm{g}$, of CoVLP, and only one type of adjuvant, $0.5 \mathrm{~mL}$ of ASO3, and Medicago planned to enroll more than 30,000 participants aged 18 years and above. The interim report on the phase 2 portion of the clinical trial was released on May 18, 2021, reiterating the safety and immunogenicity of the CoVLP vaccine indicated by the phase 1 clinical trial. Double doses of $3.75 \mu \mathrm{g}$ of CoVLP formulated with ASO3 significantly induced a humoral immune response in both age groups, although the response was greater in adults than in the elderly after a single dose [50]. The level of neutralizing antibodies induced by CoVLP plus ASO3 was 10 times higher than that observed in the convalescent sera of people who recovered from COVID-19. Vaccination with a single as well as a double dose of CoVLP plus ASO3 induced a significant cellular immune response via interferon gamma (IFN- $\gamma$ ) and IL-4 responses, which was relatively stronger in adults than in the elderly. Consistent with phase 1 trial results, adverse effects were mild to moderate and of a transient duration, such as injection site pain, muscle ache, 
and fatigue for $24 \mathrm{~h}$ to 3 days [50]. The CoVLP vaccine entered the phase 3 portion of the clinical trial on March 16, 2021. Furthermore, Medicago is developing antibodies against SARS-CoV-2 in collaboration with Laval University Canada [39].

The USFDA authorized fast-track designation for the CoVLP vaccine on 17 February 2021, and Health Canada initiated a review of the rolling submission of the CoVLP vaccine on 21 April $2021[122,123]$. This could certainly facilitate the speeding up of the vaccine's availability for public immunization. The progress made in CoVLP vaccine development represents a milestone in plant-based vaccine development history for pandemics. This could contribute to the equal distribution of the vaccine worldwide, since the CoVLP vaccine can be stored at $2-8{ }^{\circ} \mathrm{C}$, easing cold chain management with the existing infrastructure, a promising alternative to the currently available vaccines requiring ultracold storage temperatures.

\section{KBP-201: A COVID-19 cVLP Vaccine in a Phase 1/2 Clinical Trial}

US-based KBP, owned by the British American Tobacco (BAT) group, is one of the plant-based vaccine developers that has secured the second position in the race to develop a plant-based COVID-19 vaccine. The company's COVID-19 vaccine, KBP-201, is currently in a phase $1 / 2$ clinical trial (NCT04473690) [2,59]. KBP-201 is a protein subunit vaccine based on the SARS-CoV-2 receptor-binding domain (RBD) protein transiently expressed in Nicotiana benthamiana [2,52].

$\mathrm{KBP}$ also selected the $\mathrm{S}$ protein of SARS-CoV-2 for vaccine design but procured only partial sequences-that is, the RBD. The RBD is excessively exploited in COVID-19 vaccine development for its major role in virus cell entry and high immunogenicity [90-92]. The role of the $S$ protein in viral cell entry is largely contributed by the RBD. The $S$ protein is composed of two functional subunits, a receptor-binding protein, S1, constituting RBD, and a membrane fusion protein, S2. Three copies of both S1 and S2 are arranged to form a trimer with a stalk and a head, with S1 positioned as the head on the top of a stalk of S2. Viral cell entry initiates upon the attachment of S1 to the cell via the binding of the flexible RBD at its standing position with ACE2 [92,93,124,125]. Therefore, an RBD vaccine can protect the immunized organism against SARS-CoV-2 infection at the very beginning, during viral cell entry. Additionally, similar to the $S$ protein, most of the SARS-CoV-2-neutralizing antibodies from COVID-19-recovered patients are against the RBD protein [94-96], providing additional rationale for selecting the RBD for COVID-19 vaccine design.

KBP uses a unique approach to KBP-201 vaccine production, in which antigens of SARS-CoV-2 and modified tobacco mosaic virus (TMV) are separately expressed in the tobacco plant and the plant-derived RBD and TMV are chemically assembled to produce the vaccine after purification $[52,126]$. The vaccine produced by the assembly of antigen and virus is known as a chimeric VLP (cVLP) vaccine, which resembles the VLP vaccine, since, in both vaccines, a self-assembled virus creates a particle structure to provide a scaffold for displaying the target antigen. However, the cVLP vaccine is composed of an antigen-unrelated virus, which means that it displays heterologous antigens, while the VLP vaccine displays its own antigens [127].

The ability of plant viruses to form VLPs by the self-assembly of single or multiple proteins makes them ideal carrier proteins for cVLPs that can be conjugated with a foreign antigen to develop a potential vaccine [128,129]. The application of plant viruses, such as TMV, as a VLP carrier protein offers two advantages: the vaccines are safe since plant viruses are non-infectious to humans, in contrast to mammalian-origin viruses, and they can be easily produced in plants with genetically fused antigens or plant viruses. The unique combination of a plant-derived vaccine with TMV has the potential to be stable at room temperature. The first plant-virus-derived cVLP vaccine against poliovirus was developed using TMV. Afterwards, numerous plant-virus-based vaccines have been developed and evaluated for their efficacies $[36,71,130]$. 
KBP used N. benthamiana to express the RBD antigen and TMV for the rapid production of KBP-201 [131,132]. The company developed an innovative technology based on a fastgrowing tobacco plant that has superior potential to conventional vaccine production technology: speed, cost-effectiveness, scalability, robustness, and flexibility. KBP owns an automated plant growth facility that can grow 3 million tobacco plants in a climatecontrolled environment, which can be optimized to produce a protein of interest within 6-8 weeks. The adequately available plant growth facility ensures the mass production of KBP-102 immediately after completion of the clinical trial.

KBP's experiences with plant-based pharmaceutical production, especially during the 2014 Ebola outbreak, helped to accelerate COVID-19 vaccine development. During the 2014 Ebola outbreak, KBP produced three Ebola monoclonal antibodies to prepare enough cocktails to treat six affected persons at a dose of $50 \mathrm{mg} / \mathrm{kg}$ body weight [63]. The product was developed by the public health agency of Canada's National Microbiology Laboratory, the Army Medical Research Institute of Infectious Disease, USA, and Zmapp Biopharmaceuticals and was manufactured by KBP. KBP has two vaccine candidates in the pipeline, the quadrivalent seasonal influenza vaccine KBP-V001 (NCT04439695), which entered the phase 1 clinical trial in June 2020, and an influenza vaccine, which is in the preclinical development stage [133].

The phase 1/2 clinical trial of KBP-201 started on December 30, 2020. The trial is designed as an observer-blinded, randomized, placebo-controlled, parallel-group study to evaluate the safety and immunogenicity of KBP-201 plus CpG (adjuvant) in healthy SARSCoV-2 seronegative adults in two age groups: A (18-49 years) and B (50-85 years) [59]. To evaluate dose-dependent immunogenicity, each age group is divided into two subgroups, low dose and high dose, for the administration of $15 \mu \mathrm{g}$ of KBP-201 plus $0.5 \mathrm{mg}$ of CpG and $45 \mu \mathrm{g}$ of KBP-201 plus $0.5 \mathrm{mg}$ of CpG. The study subjects are randomized in a 1:1:1 ratio to receive two doses of KBP-201 by intramuscular injection at an interval of 21 days. The trial is recruiting 180 participants, and the results are yet to be published.

\section{COVID-19 Vaccines in the Preclinical Stage}

The WHO has listed 184 different COVID-19 vaccines in preclinical studies, including three plant-based vaccines [2]. In addition, plant biologists and biotech companies worldwide are developing plant-based COVID-19 vaccines, which are in the discovery and preclinical phases and are yet to be listed in the WHO vaccine list.

G+FLAS Life Sciences, Korea, transiently expressed antigens from the SARS-CoV-2 $S$ protein and RBD in $N$. benthamiana to develop a COVID-19 protein subunit vaccine and investigated the immunogenicity of the tobacco-produced antigen in mice [57]. To produce an efficient vaccine, the company used the glycoengineered tobacco plant to express antigens, since glycosylation of antigens affects the antigenicity and efficacy of the vaccine $[19,134-136]$. The $S$ protein contains $22 \mathrm{~N}$-linked glycosylation sites, indicating that differently glycosylated antigens could result in a vaccine with enhanced efficacy [137]. The glycosylation process in plants and mammals is different; thus, the glycotrait of the recombinant vaccine manufactured in two different host cells may vary, affecting its efficacy. For instance, the anti-CD20-hIL-2 immunocytokine expressed in the tobacco plant devoid of plant-specific xylose/fucose N-glycosylation shows better biological activity compared with immunocytokines obtained from animal cells, as evidenced by enhanced antibody-dependent cellular cytotoxicity and Fc-c receptor binding [138]. The preclinical study demonstrated that the G+FLAS RBD antigen with modified glycosylation can elicit a humoral immune response with the induction of highly neutralizing antibodies in mice which protected the Vero E6 cell from SARS-CoV-2 virus infection [139]. The company is expected to manufacture approximately 20,000 doses of vaccine per production cycle in the currently available plant growth facility [140].

iBio, a biotech company in the US, produced COVID-19 vaccine candidates IBIO-200, IBIO-201, and IBIO-202 by adopting two different production platforms, VLP and protein subunit vaccines, respectively [51]. In association with Texas A\&M University System 
(TAMUS), iBio developed two forms of SARS-CoV-2 VLPs, glycosylated IBIO-200 and nonglycosylated IBO-200 [141]. Both vaccine candidates, in combination with different adjuvants, were tested in mice to evaluate their immune responses, including the induction of neutralizing antibodies against SARS-CoV-2. The preclinical study revealed promising results with IBIO-201, and a subsequent in vivo toxicology study commenced. IBIO-201 is a carrier protein-conjugated subunit vaccine generated by the fusion of the $\mathrm{S}$ protein with LicKM, the company's patented booster molecule [51]. Carrier molecules are often fused with the target antigen to enhance the expression, stability, and immunogenicity of the vaccine. LicKM is an engineered thermostable lichenase enzyme originally from Clostridium thermocellum [142]. The plant-produced LicKM's conjugation with the target antigen demonstrated enhanced expression, solubility, stability, and immunogenicity of the vaccine [142-144]. The safety and protective efficacy of the LiCKM-conjugated vaccine have been evaluated against pneumonic plague in nonhuman primates $[69,145]$. The company expects an increase in the potency of subunit vaccines as well as the durability of the immune response by LicKM [146]. The fusion antigen thermostability conferred by LicKM can support the easy and cost-effective recovery of IBIO-201 during purification, since the target antigen can be separated from other proteins by heat treatment [142].

Gram quantities of high-quality IBIO-201 antigens from N. benthamiana can be produced rapidly using iBio's FastPharming system, which combines an automated hydroponic system, vertical farming, and glycan engineering technology. The FastPharming system has an accelerating feature for the development of candidate biopharmaceuticals into a clinical product. It requires 10 months for the generation of master cell banking and 14 days for manufacturing clinical products, while the mammalian cell culture system requires over 12 months and 40 days, respectively [51]. The company's glycoengineering technology can be used to produce antigens with various antigenicities to select the most effective candidate.

On 6 May 2021, iBio reported the completion of the toxicology study of IBIO-201, reporting no adverse effect at both low and high doses, which enabled the investigational new drug submission process. In addition to COVID-19 vaccines, iBio is developing a COVID-19 therapeutic ACE-Fc, ACE2 fused with the Fc region of human IgG1, in collaboration with Planet Biotechnology [147]. The company has developed the veterinary vaccine IBIO-400 for classical swine fever and IBIO-11 for fibrotic disease [51].

Baiya Phytopharm, Thailand, developed six different prototypes for COVID-19 vaccines in N. benthamiana. Of the six vaccine candidates, Baiya SARS-CoV Vax 1 was successfully tested in mice and monkeys [60]. Preclinical results demonstrated effective stimulation of neutralizing antibodies in the vaccinated animals after two doses. Based on these positive results, the company is assessing the toxicology and side effects of the vaccine. It plans to submit a proposal to the country's authorities for human trials if the candidate vaccines show efficacy and safety with low or no toxicity. The company expects to start clinical trials by the middle of 2021.

Academia from different countries also participated in the development of a plantbased COVID-19 vaccine. Chulalongkorn University, Thailand, in collaboration with Baiya Phytopharm, transiently expressed the RBD protein in N. benthamiana, and the plant-produced RBD was found to be efficiently bound to ACE2 [54]. The team used the plant-derived RBD to develop a COVID-19 detection reagent, the Baiya Rapid COVID-19 IgG/IgM test kit, using a lateral flow immunoassay (LFIA) strip. The LFIA diagnostic kit demonstrated a sensitivity and specificity of $94.1 \%$ and $98 \%$, respectively, for IgG and IgM antibodies against SARS-CoV-2 in human sera [49]. LFIA can produce test results in $15 \mathrm{~min}$ and can be visually analyzed. The team applied to Thailand's FDA for medical device approval in April 2020. The progress accomplished by the group has extended the potential of plant-based antigen production for rapid and cost-effective diagnostic kit development to combat the COVID-19 pandemic. The team has also demonstrated its capacity in plant-based heterologous protein expression and the effort toward COVID-19 by producing ACE-Fc and SARS-CoV-2 neutralizing antibodies B38 and H4 [53,55]. 
In collaboration with Cape Biopharm, the University of Cape Town expressed spike S1 and RBD antigens in $N$. benthamiana. Using these proteins, the group established an indirect enzyme-linked immunosorbent assay (ELISA) for serological tests to detect SARS-CoV-2 antibodies. The ELISA developed using plant-derived S1 and RBD antigens demonstrated sensitivity and specificity comparable to the commercial ELISA kit [56].

\section{Second-Generation COVID-19 Vaccines in the Preclinical Stage}

The constant evolution of SARS-CoV-2 through mutation, a characteristic feature of the RNA virus, has led to the emergence of more than 4000 variants globally [148]. Some of the mutations have attracted extensive attention since they have potential for increased transmissibility, increased virulence, and immune evasion, leading to reduced effectiveness of vaccines. The reduced efficacy of existing vaccines, including NVX-CoV2373, Novavax, Ad26.COV2.S, Johnson and Johnson; ChAdOx1-S, AstraZeneca, BNT162b2, Pfizer; and mRNA-1273, Moderna, against the South African variant, B.1.351, has been reported [148]. Hence, considering that most of the currently available vaccines are based on the S protein, while SARS-CoV-2 mutations are appearing on the $S$ gene sequence, there is a critical need to develop new vaccines targeting antigens other than the S protein [148-152]. Furthermore, designing multiepitope and multivalent vaccines could be an effective approach to protecting against unpredictably modifying SARS-CoV-2. The nucleocapsid (N) protein could be a potential target antigen since the $\mathrm{N}$ protein is highly immunogenic and more conserved among SARS-CoV-2 variants and other coronaviruses [153-155]. A vaccine based on an $\mathrm{N}$ protein antigen with a conserved sequence may provide broader protection against a wide range of SARS-CoV-2 variants [61]. In light of variant emergence, researchers working on plant-based vaccine production have initiated efforts for the development of second-generation vaccines.

Researchers from Akdeniz University, Turkey, expressed the S1 protein, the RBD, and the $\mathrm{N}$ protein transiently in the tobacco plant and studied the immunogenicity [156]. The group, for the first time, produced $\mathrm{N}$ antigens alone and in combination with the RBD and S1 domain in the plant, whereas most plant-based vaccine developers have targeted the RBD, S1 protein, and S protein as antigens. In addition, the group produced in vivo deglycosylated variants of these antigens by co-expression of endoglycosidase (EndoH). The plant-derived RBD and S1 antigens specifically bound to ACE2, the binding being stronger in deglycosylated versions. All the antigens (N protein, S1 protein, and the RBD) elicited high-titer antibodies in mice. Immunization with two antigens, $\mathrm{N}$ protein plus RBD, elicited high-titer antibodies compared with the RBD and N protein alone, and one dose of the N protein plus RBD was enough to produce almost the same level of antibodies as observed after two doses of the RBD and $\mathrm{N}$ protein alone. The $\mathrm{N}$ protein-based vaccine approach can be applied for the development of next-generation COVID-19 vaccines to complement the existing $S$ protein-based vaccines, as demanded by the global emergence of SARS-CoV-2 mutations and the reduced efficacy of existing vaccines against the variants. The enhanced immunogenicity of the cocktail administration of the RBD plus the N protein indicates that immunization with more than one antigen can protect without a booster dose, and a combination of different target antigens can protect from more than one variant.

On 6 May 2021, iBio announced a new subunit vaccine candidate, IBIO-202, designed to target the $\mathrm{N}$ protein as a second-generation COVID-19 vaccine aiming to resolve the vaccine efficacy issues generated by the emerging variants. iBio has proceeded with a preclinical study of IBIO-202 to identify an effective adjuvant and evaluate the efficacy of the vaccine. Furthermore, iBio is examining the potential of multisubunit vaccine candidates by targeting more than one antigen to enhance the protective efficacy of the vaccine against emerging variants [146].

\section{Conclusions and Future Perspectives}

Immunization is the most effective measure to prevent infectious diseases; hence, it has received the attention of the world in an effort to combat the COVID-19 pandemic. The 
tireless efforts of the scientific community and health workers led to the development of COVID-19 vaccines within a year of the first report of the outbreak. The plant-based vaccine production system has also been exploited to develop COVID-19 vaccines, and some of the candidate vaccines are in clinical trials. This review described the ongoing efforts in the development of plant-based COVID-19 vaccines, the progress so far, recent results of clinical trials, and strategies and technologies used for vaccine production. Plant-based vaccine candidates are mostly based on the $S$ protein of SARS-CoV-2, but a new antigen target, the N protein, is also being used by some groups. VLP, cVLP, protein subunit, and carrier molecule-fused protein subunit vaccines against COVID-19 have been developed in the tobacco plant. In addition to the vaccines, plant-based antigens are used for antigenbased diagnostic reagent development, extending the scope of the plant-based production system in response to COVID-19. The rapid mass production of a vaccine for clinical trials can be achieved with the application of a transient expression system based on viral vectors in the fast-growing and high-biomass-producing $N$. benthamiana as a host plant.

The progress of Medicago's CoVLP vaccine into phase 3 and KBP's KBP-201 into phase 1 clinical trials has manifested the plant as an effective production platform for rapid, robust, safe, and economic vaccine production to respond to the COVID-19 pandemic. The productive achievement in COVID-19 vaccine development can be regarded as a milestone in the history of plant-based biopharmaceutical development. Moreover, it can encourage authorities to accept the plant-based technique as one of the vaccine production systems and to prioritize it as part of the major plan to combat future outbreaks. The progress accomplished in COVID-19 vaccine development in the past 1.5 years emphasizes the importance of collaboration among academia and industries from multidisciplinary fields and information sharing among scientific communities for the rapid progression of vaccine development.

At the time of writing this article, 212 countries had administered 2.59 billion doses of the COVID-19 vaccines by 19 June 2021 [157,158]. Most of the vaccines require double doses for effective protection. Considering that the total population of the world is 7.9 billion, the world still needs the mass production of billions of doses. The plant-based production system may fulfill a certain percentage of the global vaccine need. However, there is a huge gap in vaccine distribution between developed and developing countries. Countries with a low economy are keeping track of the WHO Covax program for vaccination of their people. In addition, the currently available mRNA vaccine requires an ultracold storage system, which hinders the developing countries' accessibility to vaccines. Plant-based vaccine technology potentially overcomes both of these obstacles faced by developing countries by eliminating the necessity of ultralow-temperature storage systems and mass production at a low price. In other words, plant-based vaccine technology can facilitate the equitable distribution of vaccines globally.

Several new variants of SARS-CoV-2 are emerging around the world, and currently available vaccines are less responsive to these new variants. The reason may be the high rate of mutations in the $S$ protein, as most of the vaccines are based on it. In this scenario, a novel vaccine targeting a protein other than the $\mathrm{S}$ protein, such as the $\mathrm{N}$ protein, could be a potential alternative, since the $\mathrm{N}$ protein is highly immunogenic and more conserved, suggesting less vulnerability to mutation. Immunization with more than one antigen may provide satisfactory protection, eliminating the need for a booster dose. People can be immunized by a combination of different target antigens to protect against multiple strains of coronavirus. A robust production system, selection of a broad range of target antigens, and the development of multiepitope and multivalent vaccines integrated with plants could be effective approaches to overcoming the challenges created by SARS-CoV-2 mutational variants. 
Author Contributions: S.C.—conceptualization, P.M.M.—writing, review, and editing. All authors have read and agreed to the published version of the manuscript.

Funding: This project was supported by the COVID-19 vaccine R\&D program (2016GFRND-GF105) of G+FLAS Life Sciences, Inc.

Institutional Review Board Statement: Not applicable.

Informed Consent Statement: Not applicable.

Data Availability Statement: The data are included in the article.

Conflicts of Interest: The authors declare no conflict of interest.

\section{References}

1. Worldometer. COVID-19 Coronavirus Pandemic. Available online: https://www.worldometers.info/coronavirus (accessed on 19 June 2021).

2. WHO. Draft Landscape and Tracker of COVID-19 Candidate Vaccines. Available online: https://www.who.int/publications/m/ item/draftlandscape-of-covid-19-candidate-vaccines (accessed on 19 June 2021).

3. NYT. Coronavirus Vaccine Tracker. Available online: https://www.nytimes.com/interactive/2021/world/covid-vaccinationstracker.html (accessed on 19 June 2021).

4. Chen, J.R.; Liu, Y.M.; Tseng, Y.C.; Ma, C. Better influenza vaccines: An industry perspective. J. Biomed. Sci. 2020, 27, 33. [CrossRef] [PubMed]

5. Barr, I.G.; Rynehart, C.; Whitney, P.; Druce, J. SARS-CoV-2 does not replicate in embryonated hen's eggs or in MDCK cell lines. Eurosurveillance 2020, 25, 2001122. [CrossRef]

6. Li, Y.; Tenchov, R.; Smoot, J.; Liu, C.; Watkins, S.; Zhou, Q. A comprehensive review of the global efforts on COVID-19 vaccine development. ACS Cent. Sci. 2021, 7, 512-533. [CrossRef] [PubMed]

7. Rawat, K.; Kumari, P.; Saha, L. COVID-19 vaccine: A recent update in pipeline vaccines, their design and development strategies. Eur. J. Pharm. 2021, 892, 173751. [CrossRef]

8. Capell, T.; Twyman, R.M.; Armario-Najera, V.; Ma, J.K.; Schillberg, S.; Christou, P. Potential applications of plant biotechnology against SARS-CoV-2. Trends Plant Sci. 2020, 25, 635-643. [CrossRef]

9. LeBlanc, Z.; Waterhouse, P.; Bally, J. Plant-based vaccines: The way ahead? Viruses 2020, 13, 5. [CrossRef] [PubMed]

10. Lico, C.; Santi, L.; Baschieri, S.; Noris, E.; Marusic, C.; Donini, M.; Pedrazzini, E.; Maga, G.; Franconi, R.; Di Bonito, P.; et al. Plant molecular farming as a strategy against COVID-19-The Italian perspective. Front. Plant Sci. 2020, 11, 609910. [CrossRef] [PubMed]

11. McDonald, K.A.; Holtz, R.B. From farm to finger prick-A perspective on how plants can help in the fight against COVID-19. Front. Bioeng. Biotechnol. 2020, 8, 782. [CrossRef] [PubMed]

12. Rosales-Mendoza, S. Will plant-made biopharmaceuticals play a role in the fight against COVID-19? Expert Opin. Biol. Ther. 2020, 20, 545-548. [CrossRef]

13. Rosales-Mendoza, S.; Márquez-Escobar, V.A.; González-Ortega, O.; Nieto-Gómez, R.; Arévalo-Villalobos, J.I. What does plantbased vaccine technology offer to the fight against COVID-19? Vaccines 2020, 8, 183. [CrossRef]

14. Shanmugaraj, B.; Bulaon, C.J.I.; Phoolcharoen, W. Plant molecular farming: A viable platform for recombinant biopharmaceutical production. Plants 2020, 9, 842. [CrossRef]

15. Shohag, M.J.I.; Khan, F.Z.; Tang, L.; Wei, Y.; He, Z.; Yang, X. COVID-19 crisis: How can plant biotechnology help? Plants 2021, 10, 352. [CrossRef]

16. Kumar, A.U.; Kadiresen, K.; Gan, W.C.; Ling, A.P.K. Current updates and research on plant-based vaccines for coronavirus disease 2019. Clin. Exp. Vaccine Res. 2021, 10, 13-23. [CrossRef]

17. Dhama, K.; Natesan, S.; Iqbal Yatoo, M.; Patel, S.K.; Tiwari, R.; Saxena, S.K.; Harapan, H. Plant-based vaccines and antibodies to combat COVID-19: Current status and prospects. Hum. Vaccines Immunother. 2020, 16, 2913-2920. [CrossRef]

18. Tusé, D.; Nandi, S.; McDonald, K.A.; Buyel, J.F. The emergency response capacity of plant-based biopharmaceutical manufacturing-What it is and what it could be. Front. Plant. Sci. 2020, 11, 594019. [CrossRef]

19. Wolfert, M.A.; Boons, G.J. Adaptive immune activation: Glycosylation does matter. Nat. Chem. Biol. 2013, 9, 776-784. [CrossRef] [PubMed]

20. Donini, M.; Marusic, C. Current state-of-the-art in plant-based antibody production systems. Biotechnol. Lett. 2019, 41, 335-346. [CrossRef]

21. Bosch, D.; Schots, A. Plant glycans: Friend or foe in vaccine development? Expert Rev. Vaccines 2010, 9, 835-842. [CrossRef]

22. Shim, B.S.; Hong, K.J.; Maharjan, P.M.; Choe, S. Plant factory: New resource for the productivity and diversity of human and veterinary vaccines. Clin. Exp. Vaccine Res. 2019, 8, 136-139. [CrossRef] [PubMed]

23. Gleba, Y.Y.; Tuse, D.; Giritch, A. Plant viral vectors for delivery by Agrobacterium. Curr. Top. Microbiol. Immunol. 2014, 375, 155-192. [CrossRef] 
24. Yao, J.; Weng, Y.; Dickey, A.; Wang, K.Y. Plants as factories for human pharmaceuticals: Applications and challenges. Int. J. Mol. Sci. 2015, 16, 28549-28565. [CrossRef] [PubMed]

25. Lee, M.F.; Chiang, C.H.; Li, Y.L.; Wang, N.M.; Song, P.P.; Lin, S.J.; Chen, Y.H. Oral edible plant vaccine containing hypoallergen of American cockroach major allergen per a 2 prevents roach-allergic asthma in a murine model. PLoS ONE 2018, 13, e0201281. [CrossRef]

26. Moon, K.B.; Park, J.S.; Park, Y.I.; Song, I.J.; Lee, H.J.; Cho, H.S.; Jeon, J.H.; Kim, H.S. Development of systems for the production of plant-derived biopharmaceuticals. Plants 2020, 9, 30. [CrossRef]

27. Takeyama, N.; Kiyono, H.; Yuki, Y. Plant-based vaccines for animals and humans: Recent advances in technology and clinical trials. Ther. Adv. Vaccines 2015, 3, 139-154. [CrossRef]

28. Rybicki, E.P. Plant-based vaccines against viruses. Virol. J. 2014, 11, 205. [CrossRef]

29. Landry, N.; Pillet, S.; Favre, D.; Poulin, J.F.; Trépanier, S.; Yassine-Diab, B.; Ward, B.J. Influenza virus-like particle vaccines made in Nicotiana benthamiana elicit durable, poly-functional and cross-reactive T cell responses to influenza HA antigens. Clin. Immunol. 2014, 154, 164-177. [CrossRef]

30. Mett, V.; Musiychuk, K.; Bi, H.; Farrance, C.E.; Horsey, A.; Ugulava, N.; Shoji, Y.; De La Rosa, P.; Palmer, G.A.; Rabindran, S. A plant-produced influenza subunit vaccine protects ferrets against virus challenge. Influenza Other Respir. Viruses 2008, 2, 33-40. [CrossRef]

31. Pêra, F.F.P.G.; Mutepfa, D.L.R.; Khan, A.M.; Els, J.H.; Mbewana, S.; van Dijk, A.A.A.; Rybicki, E.P.; Hitzeroth, I.I. Engineering and expression of a human rotavirus candidate vaccine in Nicotiana benthamiana. Virol. J. 2015, 12, 205. [CrossRef]

32. Fischer, R.; Buyel, J.F. Molecular farming-The slope of enlightenment. Biotechnol. Adv. 2020, 40, 107519. [CrossRef]

33. Nochi, T.; Yuki, Y.; Katakai, Y.; Shibata, H.; Tokuhara, D.; Mejima, M.; Kurokawa, S.; Takahashi, Y.; Nakanishi, U.; Ono, F.; et al. A rice-based oral cholera vaccine induces macaque-specific systemic neutralizing antibodies but does not influence pre-existing intestinal immunity. J. Immunol. 2009, 183, 6538-6544. [CrossRef]

34. Govea-Alonso, D.O.; Rubio-Infante, N.; García-Hernández, A.L.; Varona-Santos, J.T.; Korban, S.S.; Moreno-Fierros, L.; RosalesMendoza, S. Immunogenic properties of a lettuce-derived C4(V3)6 multiepitopic HIV protein. Planta 2013, 238, 785-792. [CrossRef] [PubMed]

35. Kapusta, J.; Modelska, A.; Figlerowicz, M.; Pniewski, T.; Letellier, M.; Lisowa, O.; Yusibov, V.; Koprowski, H.; Plucienniczak, A.; Legocki, A.B. A plant-derived edible vaccine against hepatitis B virus. FASEB J. 1999, 13, 1796-1799. [CrossRef] [PubMed]

36. Yusibov, V.; Hooper, D.C.; Spitsin, S.V.; Fleysh, N.; Kean, R.B.; Mikheeva, T.; Deka, D.; Karasev, A.; Cox, S.; Randall, J.; et al. Expression in plants and immunogenicity of plant virus-based experimental rabies vaccine. Vaccine 2002, 20, 3155-3164. [CrossRef]

37. Chan, H.T.; Daniell, H. Plant-made oral vaccines against human infectious diseases-Are we there yet? Plant. Biotechnol. J. 2015, 13, 1056-1070. [CrossRef]

38. Kurup, V.M.; Thomas, J. Edible vaccines: Promises and challenges. Mol. Biotechnol. 2020, 62, 79-90. [CrossRef]

39. Medicago. COVID-19 Vaccine Development Program. Available online: https://www.medicago.com/en/covid-19-programs (accessed on 11 May 2021).

40. Marillonnet, S.; Thoeringer, C.; Kandzia, R.; Klimyuk, V.; Gleba, Y. Systemic Agrobacterium tumefaciens-mediated transfection of viral replicons for efficient transient expression in plants. Nat. Biotechnol. 2005, 23, 718-723. [CrossRef]

41. RT. DARPA's Blue Angel—Pentagon Prepares Millions of Vaccines Against Future Global Flu. Available online: https://www.rt. com/usa/future-vaccine-darpa-research-255 (accessed on 11 May 2021).

42. Rybicki, E.P. Plant-produced vaccines: Promise and reality. Drug Discov. Today 2009, 14, 16-24. [CrossRef]

43. Fox, J.L. First plant-made biologic approved. Nat. Biotechnol. 2012, 30, 472. [CrossRef]

44. Shaaltiel, Y.; Bartfeld, D.; Hashmueli, S.; Baum, G.; Brill-Almon, E.; Galili, G.; Dym, O.; Boldin-Adamsky, S.A.; Silman, I.; Sussman, J.L.; et al. Production of glucocerebrosidase with terminal mannose glycans for enzyme replacement therapy of Gaucher's disease using a plant cell system. Plant. Biotechnol. J. 2007, 5, 579-590. [CrossRef]

45. Mor, T.S. Molecular pharming's foot in the FDA's door: Protalix's trailblazing story. Biotechnol. Lett. 2015, 37, 2147-2150. [CrossRef]

46. Pogrebnyak, N.; Golovkin, M.; Andrianov, V.; Spitsin, S.; Smirnov, Y.; Egolf, R.; Koprowski, H. Severe acute respiratory syndrome (SARS) S protein production in plants: Development of recombinant vaccine. Proc. Natl. Acad. Sci. USA 2005, 102, 9062-9067. [CrossRef]

47. Li, H.Y.; Ramalingam, S.; Chye, M.L. Accumulation of recombinant SARS-CoV spike protein in plant cytosol and chloroplasts indicate potential for development of plant-derived oral vaccines. Exp. Biol. Med. 2006, 231, 1346-1352. [CrossRef]

48. Ward, B.J.; Makarkov, A.; Séguin, A.; Pillet, S.; Trépanier, S.; Dhaliwall, J.; Libman, M.D.; Vesikari, T.; Landry, N. Efficacy, immunogenicity, and safety of a plant-derived, quadrivalent, virus-like particle influenza vaccine in adults (18-64 years) and older adults ( $\geq 65$ years): Two multicentre, randomised phase 3 trials. Lancet 2020, 396, 1491-1503. [CrossRef]

49. Rattanapisit, K.; Yusakul, G.; Shanmugaraj, B.; Kittirotruji, K.; Suwatsrisakul, P.; Prompetchara, E.; Taychakhoonavud, S.; Phoolcharoen, W. Plant-produced recombinant SARS-CoV-2 receptor-binding domain_ an economical, scalable biomaterial source for COVID-19 diagnosis. Bimater. Transl. 2021, 43, 43-49. [CrossRef]

50. Gobeil, P.; Pillet, S.; Séguin, A.; Boulay, I.; Mahmood, A.; Vinh, D.C.; Charland, N.; Boutet, P.; Roman, F.; Van Der Most, R.; et al Interim report of a phase 2 randomized trial of a plant-produced virus-like particle vaccine for Covid-19 in healthy adults aged 18-64 and older adults aged 65 and older. medRxiv 2021. [CrossRef] 
51. IBIO. Vaccines IBIO-202 COVID-19. Available online: https://www.ibioinc.com/vaccines/ibio-202 (accessed on 11 May 2021).

52. KBP. Our Discovery Pipelines. Available online: https://kentuckybioprocessing.com/our-discovery-pipeline/\#pandemicpreparedness (accessed on 11 May 2021).

53. Siriwattananon, K.; Manopwisedjaroen, S.; Kanjanasirirat, P.; Budi Purwono, P.; Rattanapisit, K.; Shanmugaraj, B.; Smith, D.R.; Borwornpinyo, S.; Thitithanyanont, A.; Phoolcharoen, W. Development of plant-produced recombinant ACE2-Fc fusion protein as a potential therapeutic agent against SARS-CoV-2. Front. Plant. Sci. 2021, 11, 604663. [CrossRef]

54. Rattanapisit, K.; Shanmugaraj, B.; Manopwisedjaroen, S.; Purwono, P.B.; Siriwattananon, K.; Khorattanakulchai, N.; Hanittinan, O.; Boonyayothin, W.; Thitithanyanont, A.; Smith, D.R.; et al. Rapid production of SARS-CoV-2 receptor binding domain (RBD) and spike specific monoclonal antibody CR3022 in Nicotiana benthamiana. Sci. Rep. 2020, 10, 17698. [CrossRef]

55. Shanmugaraj, B.; Rattanapisit, K.; Manopwisedjaroen, S.; Thitithanyanont, A.; Phoolcharoen, W. Monoclonal antibodies B38 and H4 produced in Nicotiana benthamiana neutralize SARS-CoV-2 in vitro. Front. Plant. Sci. 2020, 11, 589995. [CrossRef]

56. Makatsa, M.S.; Tincho, M.B.; Wendoh, J.M.; Ismail, S.D.; Nesamari, R.; Pera, F.; de Beer, S.; David, A.; Jugwanth, S.; Gededzha, M.P.; et al. SARS-CoV-2 antigens expressed in plants detect antibody responses in COVID-19 patients. Front. Plant. Sci. 2021, 12, 589940. [CrossRef]

57. GLS. GFLAS Life Sciences Succeeds in Expressing COVID-19 Recombinant Vaccine Candidates with Plant Based Platform. Available online: http:/ / gflas.com/about/press_view.php?idx=165 (accessed on 11 May 2021).

58. Medicago. Medicago and GSK Start Phase 3 Trial of Adjuvanted COVID-19 Vaccine Candidate. Available online: https://www. medicago.com/en/media-room/medicago-and-gsk-start-phase-3-trial-of-adjuvanted-covid-19-vaccine-candidate (accessed on 11 May 2021).

59. ClinicalTrial. KBP-201 COVID-19 Vaccine Trial in Healthy Volunteers. Available online: https://clinicaltrials.gov/ct2/show / NCT04473690?term=KBP+201\&draw=2\&rank=1 (accessed on 11 May 2021).

60. BPP. COVID-19 Vaccine Development. Available online: https://baiyaphytopharm.com/covid-19 (accessed on 11 May 2021).

61. Mamedov, T.; Yuksel, D.; Ilgın, M.; Gürbüzaslan, İ.; Gulec, B.; Mammadova, G.; Say, D.; Hasanova, G. Engineering, production and characterization of spike and nucleocapsid structural proteins of SARS-CoV-2 in Nicotiana benthamiana as vaccine candidates against COVID-19. bioRxiv 2020. [CrossRef]

62. Mulangu, S.; Dodd, L.E.; Davey, R.T., Jr.; Tshiani Mbaya, O.; Proschan, M.; Mukadi, D.; Lusakibanza Manzo, M.; Nzolo, D.; Tshomba Oloma, A.; Ibanda, A.; et al. A randomized, controlled trial of Ebola virus disease therapeutics. N. Engl. J. Med. 2019, 381, 2293-2303. [CrossRef]

63. Zhang, Y.; Li, D.; Jin, X.; Huang, Z. Fighting Ebola with ZMapp: Spotlight on plant-made antibody. Sci. China Life Sci. 2014, 57, 987-988. [CrossRef]

64. Joung, Y.H.; Park, S.H.; Moon, K.B.; Jeon, J.H.; Cho, H.S.; Kim, H.S. The last ten years of advancements in plant-derived recombinant vaccines against hepatitis B. Int. J. Mol. Sci. 2016, 17, 1715. [CrossRef]

65. Medicago. Medicago Pipeline. Available online: https://www.medicago.com/en/pipeline (accessed on 13 May 2021).

66. Ward, B.J.; Séguin, A.; Couillard, J.; Trépanier, S.; Landry, N. Phase III: Randomized observer-blind trial to evaluate lot-to-lot consistency of a new plant-derived quadrivalent virus like particle influenza vaccine in adults 18-49 years of age. Vaccine 2021, 39, 1528-1533. [CrossRef] [PubMed]

67. Landry, N.; Ward, B.J.; Trépanier, S.; Montomoli, E.; Dargis, M.; Lapini, G.; Vézina, L.P. Preclinical and clinical development of plant-made virus-like particle vaccine against avian H5N1 influenza. PLoS ONE 2010, 5, e15559. [CrossRef]

68. Ward, B.J.; Gobeil, P.; Seguin, A.; Atkins, J.; Boulay, I.; Charbonneau, P.Y.; Couture, M.; D’Aoust, M.A.; Dhaliwall, J.; Finkle, C.; et al. Phase 1 randomized trial of a plant-derived virus-like particle vaccine for COVID-19. Nat. Med. 2021, 27, 1071-1078. [CrossRef] [PubMed]

69. Chichester, J.A.; Musiychuk, K.; Farrance, C.E.; Mett, V.; Lyons, J.; Mett, V.; Yusibov, V. A single component two-valent LcrV-F1 vaccine protects non-human primates against pneumonic plague. Vaccine 2009, 27, 3471-3474. [CrossRef] [PubMed]

70. Cummings, J.F.; Guerrero, M.L.; Moon, J.E.; Waterman, P.; Nielsen, R.K.; Jefferson, S.; Gross, F.L.; Hancock, K.; Katz, J.M.; Yusibov, V. Safety and immunogenicity of a plant-produced recombinant monomer hemagglutinin-based influenza vaccine derived from influenza A (H1N1)pdm09 virus: A phase 1 dose-escalation study in healthy adults. Vaccine 2014, 32, 2251-2259. [CrossRef] [PubMed]

71. Jones, R.M.; Chichester, J.A.; Mett, V.; Jaje, J.; Tottey, S.; Manceva, S.; Casta, L.J.; Gibbs, S.K.; Musiychuk, K.; Shamloul, M.; et al. A plant-produced Pfs25 VLP malaria vaccine candidate induces persistent transmission blocking antibodies against Plasmodium falciparum in immunized mice. PLoS ONE 2013, 8, e79538. [CrossRef] [PubMed]

72. Chichester, J.A.; Green, B.J.; Jones, R.M.; Shoji, Y.; Miura, K.; Long, C.A.; Lee, C.K.; Ockenhouse, C.F.; Morin, M.J.; Streatfield, S.J.; et al. Safety and immunogenicity of a plant-produced Pfs25 virus-like particle as a transmission blocking vaccine against malaria: A phase 1 dose-escalation study in healthy adults. Vaccine 2018, 36, 5865-5871. [CrossRef]

73. Chichester, J.A.; Jones, R.M.; Green, B.J.; Stow, M.; Miao, F.; Moonsammy, G.; Streatfield, S.J.; Yusibov, V. Safety and immunogenicity of a plant-produced recombinant hemagglutinin-based influenza vaccine (HAI-05) derived from A/Indonesia/05/2005 (H5N1) influenza virus: A phase 1 randomized, double-blind, placebo-controlled, dose-escalation study in healthy adults. Viruses 2012, 4, 3227-3244. [CrossRef] [PubMed] 
74. Pillet, S.; Racine, T.; Nfon, C.; Di Lenardo, T.Z.; Babiuk, S.; Ward, B.J.; Kobinger, G.P.; Landry, N. Plant-derived H7 VLP vaccine elicits protective immune response against H7N9 influenza virus in mice and ferrets. Vaccine 2015, 33, 6282-6289. [CrossRef] [PubMed]

75. Kashima, K.; Yuki, Y.; Mejima, M.; Kurokawa, S.; Suzuki, Y.; Minakawa, S.; Takeyama, N.; Fukuyama, Y.; Azegami, T.; Tanimoto, T.; et al. Good manufacturing practices production of a purification-free oral cholera vaccine expressed in transgenic rice plants Plant. Cell Rep. 2016, 35, 667-679. [CrossRef] [PubMed]

76. Thanavala, Y.; Mahoney, M.; Pal, S.; Scott, A.; Richter, L.; Natarajan, N.; Goodwin, P.; Arntzen, C.J.; Mason, H.S. Immunogenicity in humans of an edible vaccine for hepatitis B. Proc. Natl. Acad. Sci. USA 2005, 102, 3378-3382. [CrossRef] [PubMed]

77. Tacket, C.O.; Mason, H.S.; Losonsky, G.; Estes, M.K.; Levine, M.M.; Arntzen, C.J. Human immune responses to a novel Norwalk virus vaccine delivered in transgenic potatoes. J. Infect. Dis. 2000, 182, 302-305. [CrossRef]

78. IconGenetics. Icon Genetics Clinical Development of Its Novel Norovirus vaccine Reaches Milestone of Complete Dosing of the First Cohort. Available online: https:/ / www.icongenetics.com/icon-genetics-clinical-development-of-its-novel-norovirusvaccine-reaches-milestone-of-complete-dosing-of-the-first-cohort (accessed on 19 June 2021).

79. Pillet, S.; Aubin, É.; Trépanier, S.; Poulin, J.-F.; Yassine-Diab, B.; Ter Meulen, J.; Ward, B.J.; Landry, N. Humoral and cell-mediated immune responses to $\mathrm{H} 5 \mathrm{~N} 1$ plant-made virus-like particle vaccine are differentially impacted by alum and GLA-SE adjuvants in a Phase 2 clinical trial. NPJ Vaccines 2018, 3, 3. [CrossRef]

80. Alvarez, M.L.; Cardineau, G.A. Prevention of bubonic and pneumonic plague using plant-derived vaccines. Biotechnol. Adv. 2010, 28, 184-196. [CrossRef]

81. Arlen, P.A.; Singleton, M.; Adamovicz, J.J.; Ding, Y.; Davoodi-Semiromi, A.; Daniell, H. Effective plague vaccination via oral delivery of plant cells expressing F1-V antigens in chloroplasts. Infect. Immun. 2008, 76, 3640-3650. [CrossRef]

82. Rubio-Infante, N.; Govea-Alonso, D.O.; Romero-Maldonado, A.; García-Hernández, A.L.; Ilhuicatzi-Alvarado, D.; SalazarGonzález, J.A.; Korban, S.S.; Rosales-Mendoza, S.; Moreno-Fierros, L. A plant-derived multi-HIV antigen induces broad immune responses in orally immunized mice. Mol. Biotechnol. 2015, 57, 662-674. [CrossRef]

83. Tottey, S.; Shoji, Y.; Jones, R.M.; Chichester, J.A.; Green, B.J.; Musiychuk, K.; Si, H.; Manceva, S.D.; Rhee, A.; Shamloul, M.; et al. Plant-produced subunit vaccine candidates against yellow fever induce virus neutralizing antibodies and confer protection against viral challenge in animal models. Am. J. Trop. Med. Hyg. 2018, 98, 420-431. [CrossRef]

84. Guimarães, R.; Fernandes, A.; Simões, M.; Marchevsky, R.; Neves, P.; Bom, A.; Caride, E.; Freire, M. Yellow fever vaccine, recombinant envelope protein (rYFE), plant derived, for active immunization: Pre-clinical studies in mice and monkey models. In Proceedings of the Seminario Annual Cientifico e Technology de Biomanguinhos, Rio de Janeiro, Brazil, 2-4 May 2017; pp. 52-53.

85. Tremouillaux-Guiller, J.; Moustafa, K.; Hefferon, K.; Gaobotse, G.; Makhzoum, A. Plant-made HIV vaccines and potential candidates. Curr. Opin. Biotechnol. 2020, 61, 209-216. [CrossRef] [PubMed]

86. Lindh, I.; Bråve, A.; Hallengärd, D.; Hadad, R.; Kalbina, I.; Strid, Å.; Andersson, S. Oral delivery of plant-derived HIV-1 p24 antigen in low doses shows a superior priming effect in mice compared to high doses. Vaccine 2014, 32, 2288-2293. [CrossRef] [PubMed]

87. Phoolcharoen, W.; Bhoo, S.H.; Lai, H.; Ma, J.; Arntzen, C.J.; Chen, Q.; Mason, H.S. Expression of an immunogenic Ebola immune complex in Nicotiana Benthamiana. Plant. Biotechnol. J. 2011, 9, 807-816. [CrossRef]

88. Van Eerde, A.; Gottschamel, J.; Bock, R.; Hansen, K.E.A.; Munang'andu, H.M.; Daniell, H.; Liu Clarke, J. Production of tetravalent dengue virus envelope protein domain III based antigens in lettuce chloroplasts and immunologic analysis for future oral vaccine development. Plant. Biotechnol. J. 2019, 17, 1408-1417. [CrossRef]

89. Ponndorf, D.; Meshcheriakova, Y.; Thuenemann, E.C.; Dobon Alonso, A.; Overman, R.; Holton, N.; Dowall, S.; Kennedy, E.; Stocks, M.; Lomonossoff, G.P.; et al. Plant-made dengue virus-like particles produced by co-expression of structural and non-structural proteins induce a humoral immune response in mice. Plant. Biotechnol. J. 2021, 19, 745-756. [CrossRef] [PubMed]

90. Wang, M.Y.; Zhao, R.; Gao, L.J.; Gao, X.F.; Wang, D.P.; Cao, J.M. SARS-CoV-2: Structure, biology, and structure-based therapeutics development. Front. Cell Infect. Microbiol. 2020, 10, 587269. [CrossRef]

91. Karamloo, F.; König, R. SARS-CoV-2 immunogenicity at the crossroads. Allergy 2020, 75, 1822-1824. [CrossRef]

92. Wrapp, D.; Wang, N.; Corbett, K.S.; Goldsmith, J.A.; Hsieh, C.L.; Abiona, O.; Graham, B.S.; McLellan, J.S. Cryo-EM structure of the 2019-nCoV spike in the prefusion conformation. Science 2020, 367, 1260-1263. [CrossRef] [PubMed]

93. Papageorgiou, A.C.; Mohsin, I. The SARS-CoV-2 spike glycoprotein as a drug and vaccine target: Structural insights into its complexes with ACE2 and antibodies. Cells 2020, 9, 2343. [CrossRef] [PubMed]

94. Brouwer, P.J.M.; Caniels, T.G.; van der Straten, K.; Snitselaar, J.L.; Aldon, Y.; Bangaru, S.; Torres, J.L.; Okba, N.M.A.; Claireaux, M.; Kerster, G.; et al. Potent neutralizing antibodies from COVID-19 patients define multiple targets of vulnerability. Science 2020, 369, 643-650. [CrossRef]

95. Bao, Y.; Ling, Y.; Chen, Y.Y.; Tian, D.; Zhao, G.P.; Zhang, X.H.; Hang, H.; Li, Y.; Su, B.; Lu, H.Z.; et al. Dynamic anti-spike protein antibody profiles in COVID-19 patients. Int. J. Infect. Dis. 2021, 103, 540-548. [CrossRef] [PubMed]

96. Salazar, E.; Kuchipudi, S.V.; Christensen, P.A.; Eagar, T.; Yi, X.; Zhao, P.; Jin, Z.; Long, S.W.; Olsen, R.J.; Chen, J.; et al. Convalescent plasma anti-SARS-CoV-2 spike protein ectodomain and receptor-binding domain IgG correlate with virus neutralization. J. Clin. Investig. 2020, 130, 6728-6738. [CrossRef]

97. Noad, R.; Roy, P. Virus-like particles as immunogens. Trends Microbiol. 2003, 11, 438-444. [CrossRef] 
98. Liu, F.; Ge, S.; Li, L.; Wu, X.; Liu, Z.; Wang, Z. Virus-like particles: Potential veterinary vaccine immunogens. Res. Vet. Sci. 2012, 93, 553-559. [CrossRef] [PubMed]

99. D'Aoust, M.A.; Couture, M.M.J.; Charland, N.; Trépanier, S.; Landry, N.; Ors, F.; Vézina, L.P. The production of hemagglutininbased virus-like particles in plants: A rapid, efficient and safe response to pandemic influenza. Plant. Biotechnol. J. 2010, 8 , 607-619. [CrossRef]

100. Jennings, G.T.; Bachmann, M.F. The coming of age of virus-like particle vaccines. Biol. Chem. 2008, 389, 521-536. [CrossRef]

101. Chackerian, B.; Lenz, P.; Lowy, D.R.; Schiller, J.T. Determinants of autoantibody induction by conjugated papillomavirus virus-like particles. J. Immunol. 2002, 169, 6120-6126. [CrossRef] [PubMed]

102. Ludwig, C.; Wagner, R. Virus-like particles-universal molecular toolboxes. Curr. Opin. Biotechnol. 2007, 18, 537-545. [CrossRef] [PubMed]

103. Roldão, A.; Mellado, M.C.; Castilho, L.R.; Carrondo, M.J.; Alves, P.M. Virus-like particles in vaccine development. Expert Rev. Vaccines 2010, 9, 1149-1176. [CrossRef]

104. Huang, Z.; Elkin, G.; Maloney, B.J.; Beuhner, N.; Arntzen, C.J.; Thanavala, Y.; Mason, H.S. Virus-like particle expression and assembly in plants: Hepatitis B and Norwalk viruses. Vaccine 2005, 23, 1851-1858. [CrossRef]

105. Mohsen, M.O.; Gomes, A.C.; Vogel, M.; Bachmann, M.F. Interaction of viral capsid-derived virus-like particles (VLPs) with the innate immune system. Vaccines 2018, 6, 37. [CrossRef]

106. D’Aoust, M.A.; Lavoie, P.O.; Couture, M.M.; Trépanier, S.; Guay, J.M.; Dargis, M.; Mongrand, S.; Landry, N.; Ward, B.J.; Vézina, L.P. Influenza virus-like particles produced by transient expression in Nicotiana benthamiana induce a protective immune response against a lethal viral challenge in mice. Plant. Biotechnol. J. 2008, 6, 930-940. [CrossRef] [PubMed]

107. Shoji, Y.; Farrance, C.E.; Bautista, J.; Bi, H.; Musiychuk, K.; Horsey, A.; Park, H.; Jaje, J.; Green, B.J.; Shamloul, M.; et al. A plant-based system for rapid production of influenza vaccine antigens. Influenza Other Respir. Viruses 2012, 6, 204-210. [CrossRef] [PubMed]

108. Streatfield, S.J.; Kushnir, N.; Yusibov, V. Plant-produced candidate countermeasures against emerging and reemerging infections and bioterror agents. Plant Biotechnol. J. 2015, 13, 1136-1159. [CrossRef]

109. Medicago. Discovery Platforms. Available online: https://www.medicago.com/en/discovery (accessed on 11 May 2021).

110. Reed, S.G.; Orr, M.T.; Fox, C.B. Key roles of adjuvants in modern vaccines. Nat. Med. 2013, 19, 1597-1608. [CrossRef]

111. Liang, Z.; Zhu, H.; Wang, X.; Jing, B.; Li, Z.; Xia, X.; Sun, H.; Yang, Y.; Zhang, W.; Shi, L. Adjuvants for coronavirus vaccines. Front. Immunol. 2020, 11, 2896. [CrossRef] [PubMed]

112. O'Hagan, D.T.; Lodaya, R.N.; Lofano, G. The continued advance of vaccine adjuvants—'We can work it out'. In Seminars in Immunology; Academic Press: Cambridge, MA, USA, 2020; p. 101426.

113. Campbell, J.D. Development of the CpG adjuvant 1018: A case study. Methods Mol. Biol. 2017, 1494, 15-27. [PubMed]

114. Schillie, S.; Harris, A.; Link-Gelles, R.; Romero, J.; Ward, J.; Nelson, N. Recommendations of the advisory committee on immunization practices for use of a hepatitis B vaccine with a novel adjuvant. Morb. Mortal. Wkly. Rep. 2018, 67, 455. [CrossRef] [PubMed]

115. Dynavax. CpG 1018. Available online: https:/ / www.dynavax.com/science/cpg-1018 (accessed on 11 May 2021).

116. Garçon, N.; Vaughn, D.W.; Didierlaurent, A.M. Development and evaluation of AS03, an adjuvant system containing $\alpha$-tocopherol and squalene in an oil-in-water emulsion. Expert Rev. Vaccines 2012, 11, 349-366. [CrossRef] [PubMed]

117. Cohet, C.; van der Most, R.; Bauchau, V.; Bekkat-Berkani, R.; Doherty, T.M.; Schuind, A.; Tavares Da Silva, F.; Rappuoli, R.; Garçon, N.; Innis, B.L. Safety of AS03-adjuvanted influenza vaccines: A review of the evidence. Vaccine 2019, 37, 3006-3021. [CrossRef]

118. Nature. How Plants Could Produce a COVID-19 Vaccine. Available online: https://www.nature.com/articles/d42473-020-00253 -2 (accessed on 11 May 2021).

119. Medicago. Medicago Announces Positive Phase 1 Results for Its COVID-19 Vaccine Candidate. Available online: https://www. medicago.com/en/media-room/medicago-announces-positive-phase-1-results-for-its-covid-19-vaccine-candidate (accessed on 11 May 2021).

120. ClinicalTrial. Safety, Tolerability and Immunogenicinity of a Coronavirus-Like Particle COVID-19 Vaccine in Adults Aged 18-55 Years. Available online: https: / / clinicaltrials.gov/ct2/ show / NCT04450004?term=CoVLP\&draw=2 (accessed on 11 May 2021).

121. Medicago. Medicago and GSK Announce Start of Phase 2/3 Clinical Trials of Adjuvanted COVID-19 Vaccine Candidate. Available online: https://www.medicago.com/en/media-room/medicago-and-gsk-announce-start-of-phase-2-3-clinical-trialsof-adjuvanted-covid-19-vaccine-candidate (accessed on 11 May 2021).

122. PMLiVE. GSK and Medicago Initiate Late-Stage COVID-19 Vaccine Study. Available online: http://www.pmlive.com/pharma_ news/gsk_and_medicago_initiate_late-stage_covid-19_vaccine_study_1365425 (accessed on 11 May 2021).

123. Medicago. Health Canada Initiates the Review of the Rolling Submission for the First Canadian-based COVID-19 Vaccine Candidate. Available online: https://www.medicago.com/en/media-room/health-canada-initiates-the-review-of-the-rollingsubmission-for-the-first-canadian-based-covid-19-vaccine-candidate (accessed on 11 May 2021).

124. Li, F.; Li, W.; Farzan, M.; Harrison, S.C. Structure of SARS coronavirus spike receptor-binding domain complexed with receptor. Science 2005, 309, 1864-1868. [CrossRef]

125. Walls, A.C.; Park, Y.J.; Tortorici, M.A.; Wall, A.; McGuire, A.T.; Veesler, D. Structure, function, and antigenicity of the SARS-CoV-2 spike glycoprotein. Cell 2020, 181, 281-292.e286. [CrossRef] [PubMed] 
126. NPR. Tobacco Plants Contribute Key Ingredient for COVID-19 Vaccine. Available online: https:/ /www.npr.org/sections/healthshots/2020/10/15/923210562/tobacco-plants-contribute-key-ingredient-for-covid-19-vaccine (accessed on 11 May 2021).

127. Chen, Q.; Lai, H. Plant-derived virus-like particles as vaccines. Hum. Vaccines Immunother. 2013, 9, 26-49. [CrossRef] [PubMed]

128. Emini, E.A.; Jameson, B.A.; Wimmer, E. Priming for and induction of anti-poliovirus neutralizing antibodies by synthetic peptides. Nature 1983, 304, 699-703. [CrossRef]

129. Butler, P.J.G. The current picture of the structure and assembly of tobacco mosaic virus. J. Gen. Virol. 1984, 65, 253-279. [CrossRef]

130. Haynes, J.R.; Cunningham, J.; von Seefried, A.; Lennick, M.; Garvin, R.T.; Shen, S.H. Development of a genetically-engineered, candidate polio vaccine employing the self-assembling properties of the tobacco mosaic virus coat protein. Bio/Technology 1986, 4, 637-641. [CrossRef] [PubMed]

131. BPN. BAT Biotech Using Tobacco to Make COVID-19 Vaccine Candidate. Available online: https://bioprocessintl.com/ bioprocess-insider/therapeutic-class/bat-biotech-using-tobacco-to-make-covid-19-vaccine-candidate (accessed on 11 May 2021).

132. BAT. BAT Progresses COVID-19 Candidate Vaccine into Phase I Human Clinical Trials. Available online: https:/ /www.batscience.com/GROUPMS/SITES/BAT_B9JBW3.NSF/vwPagesWebLive/DOBVULEJ (accessed on 11 May 2021).

133. ClinicalTrial. Study to Evaluate the Safety and Immunogenicity of KBP-V001 Quadrivalent Influenza Vaccine in Healthy Adults. Available online: https:/ / clinicaltrials.gov / ct2/ show / NCT04439695?term=Kentucky+bioprocessing\&draw=2\&rank=2 (accessed on 12 May 2021).

134. Wintjens, R.; Bifani, A.M.; Bifani, P. Impact of glycan cloud on the B-cell epitope prediction of SARS-CoV-2 Spike protein. NPJ Vaccines 2020, 5, 81. [CrossRef]

135. Ozdilek, A.; Paschall, A.V.; Dookwah, M.; Tiemeyer, M.; Avci, F.Y. Host protein glycosylation in nucleic acid vaccines as a potential hurdle in vaccine design for nonviral pathogens. Proc. Natl. Acad. Sci. USA 2020, 117, 1280-1282. [CrossRef] [PubMed]

136. BS. G+Flas, Setting a Development of Plant-Based ‘COVID-19' Vaccine. Available online: http://www.biospectator.com/view / news_view.php?varAtcId=9750 (accessed on 11 May 2021).

137. Watanabe, Y.; Allen, J.D.; Wrapp, D.; McLellan, J.S.; Crispin, M. Site-specific glycan analysis of the SARS-CoV-2 spike. Science 2020, 369, 330-333. [CrossRef]

138. Marusic, C.; Pioli, C.; Stelter, S.; Novelli, F.; Lonoce, C.; Morrocchi, E.; Benvenuto, E.; Salzano, A.M.; Scaloni, A.; Donini, M. N-glycan engineering of a plant-produced anti-CD20-hIL-2 immunocytokine significantly enhances its effector functions. Biotechnol. Bioeng. 2018, 115, 565-576. [CrossRef]

139. Maharjan, P.M.; Cheon, J.; Jung, J.; Kim, H.; Lee, J.; Song, M.; Jeong, G.U.; Kwon, Y.; Shim, B.; Choe, S. Plant-Expressed Receptor Binding Domain of the SARS-CoV-2 Spike Protein Elicits Humoral Immunity in Mice. Vaccines 2021, 9, 978. [CrossRef]

140. Pulse. G+FLAS Life Sciences Readying Animal Testing of Coronavirus Vaccine Candidate. Available online: https:/ pulsenews. co.kr / view.php?year=2020\&no=236363 (accessed on 11 May 2021).

141. CNN. iBio Announces Advancement of COVID-19 Vaccine Program. Available online: https://edition.cnn.com/business/ newsfeeds/globenewswire/7874773.html (accessed on 25 April 2021).

142. Musiychuk, K.; Stephenson, N.; Bi, H.; Farrance, C.E.; Orozovic, G.; Brodelius, M.; Brodelius, P.; Horsey, A.; Ugulava, N.; Shamloul, A.M. A launch vector for the production of vaccine antigens in plants. Influenza Other Respir. Viruses 2007, 1, 19-25. [CrossRef] [PubMed]

143. Massa, S.; Franconi, R.; Brandi, R.; Muller, A.; Mett, V.; Yusibov, V.; Venuti, A. Anti-cancer activity of plant-produced HPV16 E7 vaccine. Vaccine 2007, 25, 3018-3021. [CrossRef]

144. Buyel, J.F.; Bautista, J.A.; Fischer, R.; Yusibov, V.M. Extraction, purification and characterization of the plant-produced HPV16 subunit vaccine candidate E7 GGG. J. Chromatogr B Anal. Technol. Biomed. Life Sci. 2012, 880, 19-26. [CrossRef] [PubMed]

145. Venuti, A.; Curzio, G.; Mariani, L.; Paolini, F. Immunotherapy of HPV-associated cancer: DNA/plant-derived vaccines and new orthotopic mouse models. Cancer Immunol. Immunother. 2015, 64, 1329-1338. [CrossRef]

146. IGN. iBio Reports Successful COVID-19 Vaccine Toxicology Study Results and Announces Next-Gen COVID-19 Vaccine Program. Available online: Globenewswire.com/news-release/2021/05/06/2225071/0/en/iBio-Reports-Successful-COVID-19-VaccineToxicology-Study-Results-and-Announces-Next-Gen-COVID-19-Vaccine-Program.html (accessed on 11 May 2021).

147. IGN. iBio and Planet Biotechnology Enter into Exclusive Worldwide License Agreement FOR THE Development of a COVID-19 Therapeutic. Available online: https://www.globenewswire.com/fr/news-release/2020/08/28/2085354/0/en/iBio-and-PlanetBiotechnology-Enter-into-Exclusive-Worldwide-License-Agreement-for-the-Development-of-a-COVID-19-Therapeutic.html (accessed on 11 May 2021).

148. Bian, L.; Gao, F.; Zhang, J.; He, Q.; Mao, Q.; Xu, M.; Liang, Z. Effects of SARS-CoV-2 variants on vaccine efficacy and response strategies. Expert Rev. Vaccines 2021, 20,365-373. [CrossRef]

149. Li, Q.; Wu, J.; Nie, J.; Zhang, L.; Hao, H.; Liu, S.; Zhao, C.; Zhang, Q.; Liu, H.; Nie, L. The impact of mutations in SARS-CoV-2 spike on viral infectivity and antigenicity. Cell 2020, 182, 1284-1294. [CrossRef]

150. Faria, N.R.; Mellan, T.A.; Whittaker, C.; Claro, I.M.; Candido, D.D.S.; Mishra, S.; Crispim, M.A.E.; Sales, F.C.S.; Hawryluk, I.; McCrone, J.T.; et al. Genomics and epidemiology of the P.1 SARS-CoV-2 lineage in Manaus, Brazil. Science 2021, 372, 815-821. [CrossRef]

151. Tegally, H.; Wilkinson, E.; Giovanetti, M.; Iranzadeh, A.; Fonseca, V.; Giandhari, J.; Doolabh, D.; Pillay, S.; San, E.J.; Msomi, N.; et al. Emergence and rapid spread of a new severe acute respiratory syndrome-related coronavirus 2 (SARS-CoV-2) lineage with multiple spike mutations in South Africa. medRxiv 2020. [CrossRef] 
152. Rambaut, A.; Holmes, E.C.; O’Toole, Á.; Hill, V.; McCrone, J.T.; Ruis, C.; du Plessis, L.; Pybus, O.G. A dynamic nomenclature proposal for SARS-CoV-2 lineages to assist genomic epidemiology. Nat. Microbiol. 2020, 5, 1403-1407. [CrossRef] [PubMed]

153. Dutta, N.K.; Mazumdar, K.; Gordy, J.T. The nucleocapsid protein of SARS-CoV-2: A target for vaccine development. J. Virol. 2020, 94, e00647-20. [CrossRef] [PubMed]

154. Oliveira, S.C.; de Magalhães, M.T.Q.; Homan, E.J. Immunoinformatic analysis of SARS-CoV-2 nucleocapsid protein and identification of COVID-19 vaccine targets. Front. Immunol. 2020, 11, 587615. [CrossRef] [PubMed]

155. Kang, S.; Yang, M.; Hong, Z.; Zhang, L.; Huang, Z.; Chen, X.; He, S.; Zhou, Z.; Zhou, Z.; Chen, Q.; et al. Crystal structure of SARS-CoV-2 nucleocapsid protein RNA binding domain reveals potential unique drug targeting sites. Acta Pharm. Sin. B 2020, 10, 1228-1238. [CrossRef]

156. Liu, W.; Liu, L.; Kou, G.; Zheng, Y.; Ding, Y.; Ni, W.; Wang, Q.; Tan, L.; Wu, W.; Tang, S.; et al. Evaluation of nucleocapsid and spike protein-based enzyme-linked immunosorbent assays for detecting antibodies against SARS-CoV-2. J. Clin. Microbiol. 2020, 58, e00461-20. [CrossRef]

157. NYT. Tracking Coronavirus Vaccinations around the World. Available online: https://www.nytimes.com/interactive/2021 / world/covid-vaccinations-tracker.html (accessed on 19 June 2021).

158. CNN. Tracking Covid-19 Vaccinations Worldwide. Available online: https://edition.cnn.com/interactive/2021/health/globalcovid-vaccinations (accessed on 19 June 2021). 